\title{
Antibacterial activity of Apocynaceae extracts and MIC of Tabernaemontana angulata stem organic extract
}

\author{
Ivana Barbosa Suffredini ${ }^{1 *}$, Elfriede Marianne Bacchi², Telma Mary Kaneko Sakuda², \\ Mitsuko Taba Ohara ${ }^{2}$, Riad Naim Younes ${ }^{1}$, Antonio Drauzio Varella ${ }^{1}$
}

Laboratório de Extração, Centro de Pesquisas Oncológicas da Universidade Paulista, ${ }^{2}$ Departamento de Farmácia, Faculdade de Ciências Farmacêuticas da Universidade de São Paulo.

*Correspondence:

Ivana B. Suffredini

Laboratório de Extração

Centro de Pesquisas Oncológicas

Universidade Paulista

Av. Paulista, 900, $1^{\circ}$ andar

01310-100 - São Paulo, SP, Brasil

E-mail: extractlab@unip-objetivo.br
Thirty-eight aqueous and organic extracts obtained from 11 Amazonian Apocynaceae species were submitted to an antimicrobial dilution in broth media screening for Staphylococcus aureus, Pseudomonas aeruginosa and Candida albicans, performed on microtiter plates. The organic extract obtained from the stem of Tabernaemontana angulata presented activity against Gram positive Staphylococcus aureus. The minimal inhibitory concentration of the organic crude extract was 2.50-1.25 $\mathrm{mg} / \mathrm{mL}$. Cloramphenicol was used as standard. Alkaloids and triterpenes were found in the active organic extract.

\section{INTRODUCTION}

The Amazon Rain Forest is home to $20 \%$ of the biodiversity found in the world. The Rio Negro Basin has unique features not found elsewhere, as it is the converging point of species richness endemic to distant locations, markedly the Lower Rio Negro, near the city of Manaus (Oliveira, Daly, 1999). The interest in finding new antimicrobial substances becomes evident and mechanisms of action related to bacterial resistance are elucidated (Moellering, 1998). Apocynaceae has been chosen as a group to be evaluated in this study because of its popular use (Duke, Vasquez, 1994), chemosystematic correlations (Cronquist, 1988) and pharmacognostic interest.

\section{MATERIALS AND METHODS}

\section{Plant material}

All plants were collected in the Amazon Rain Forest under authorization of Instituto Brasileiro do Meio Ambi- ente e dos Recursos Naturais Renováveis - IBAMA numbers $053 / 99$ and 038/99. The selected species are listed in Table I, together with sites of collection, herbarium and collector's number, parts used and types of extract (organic or aqueous). Vouchers are deposited in the Herbarium UNIP and were authenticated by Dr. Alexandre A. de Oliveira.

\section{Preparation of crude extracts}

Plant parts were separated, dried in a stove at $40^{\circ} \mathrm{C}$, ground, labeled and stored in a freezer until use. Extractions were carried out in a glass percolator, and an organic $\left(\mathrm{CH}_{2} \mathrm{Cl}_{2}: \mathrm{H}_{3} \mathrm{COH}, 1: 1\right)$ and an aqueous 24 hourmacerate were obtained from each sample. Organic extracts were rotavaporated and the aqueous ones were lyophilized (Younes et al., 2000).

\section{Antimicrobial assay}

Staphylococcus aureus (ATCC 6538), Pseudomonas aeruginosa (ATCC 9027) and Candida 
TABLE I - Species of Apocynaceae used to obtain crude extracts to be screened against $S$. aureus, P. aeruginosa and $C$. albicans by the dilution in broth media test. Collector's and herbarium numbers, sites of collection and parts used are given, as well as extract numbers and information whether the extract is organic (O) or aqueous (A)

\begin{tabular}{|c|c|c|c|c|}
\hline Species & $\begin{array}{l}\text { Collector's } \\
\text { number }\end{array}$ & $\begin{array}{l}\text { Herbarium } \\
\text { number }\end{array}$ & $\begin{array}{l}\text { Place } \\
\text { of collection }\end{array}$ & $\begin{array}{l}\text { Parts used (extract } \\
\text { number and status) }\end{array}$ \\
\hline Aspidosperma pachypterum Müell.-Arg & AAO 3263 & 000364 & Igapó Forest & $\begin{array}{l}\text { Stem }(1, \mathrm{O} ; 2, \mathrm{~A}) \text {; bark } \\
(3, \mathrm{O} ; 4, \mathrm{~A}) \text {; roots }(5, \mathrm{O} ; \\
6, \mathrm{~A}) \text {; stem }+ \text { leaves }(7, \mathrm{O} \text {; } \\
8, \mathrm{~A})\end{array}$ \\
\hline Aspidosperma sp. & PS 360 & 000276 & Igapó Forest & $\begin{array}{l}\text { Stem+leaves }(9, \mathrm{O} ; 10, \mathrm{~A}) \\
\text { stem }(11, \mathrm{O} ; 12 \mathrm{~A})\end{array}$ \\
\hline Couma utilis (Mart.) Müell.-Arg & AAO 3336 & 000478 & Terra firme Forest & $\begin{array}{l}\text { Stem }(13,0) \text {; leaves } \\
(14,0 ; 15 \mathrm{~A})\end{array}$ \\
\hline $\begin{array}{l}\text { Himatanthus attenuatus (Benth.) } \\
\text { Woodson }\end{array}$ & PS 150 & 000074 & Igapó Forest & $\begin{array}{l}\text { Leaves } \\
(16, \mathrm{O} ; 17 \mathrm{~A}) \text {; stem }(18, \mathrm{O} \text {; } \\
19, \mathrm{~A})\end{array}$ \\
\hline $\begin{array}{l}\text { Macoubea sprucei.( Müell.-Arg) } \\
\text { Markgr. }\end{array}$ & AAO 3373 & 000515 & Campinarana $^{3}$ & Stem $(20,0)$; fruit $(21,0)$ \\
\hline Malouetia tamaquarina (Aubl.) A. DC. & IBS 10 & 000444 & Igapó $^{1}$ Forest & $\begin{array}{l}\text { Aerial parts }(22, \mathrm{O} ; 23, \mathrm{~A}) \text {; } \\
\text { stem }(24, \mathrm{O} ; 25, \mathrm{~A})\end{array}$ \\
\hline Mandevilla rugosa (Benth.) Woodson & AAO 3354 & 000496 & Igapó ${ }^{1}$ Forest & Aerial parts $(26,0)$ \\
\hline $\begin{array}{l}\text { Microplumeria anomala (Müell.-Arg) } \\
\text { Markgr. }\end{array}$ & PS 136 & 000060 & Igapó $^{1}$ Forest & $\begin{array}{l}\text { Stem }(27, \mathrm{O} ; 28, \mathrm{~A}) \\
\text { leaves }(29, \mathrm{O} ; 30, \mathrm{~A})\end{array}$ \\
\hline $\begin{array}{l}\text { Odontadenia macrantha } \\
\text { (Roem. \& Schult.) Markgr. }\end{array}$ & PS 94 & 000018 & Igapó $^{1}$ Forest & $\begin{array}{l}\text { Stem+leaves }(31, \mathrm{O} \text {; } \\
32, \mathrm{~A}) \text {; } \operatorname{stem}(33, \mathrm{O} ; 34, \mathrm{~A})\end{array}$ \\
\hline $\begin{array}{l}\text { Tabernaemontana angulata } \\
\text { (Mart. ex Müell.Arg) }\end{array}$ & PS 416 & 000321 & $\begin{array}{l}\text { Igapó } 1 / \text { terra } \\
\text { firme }^{2} \text { forest }\end{array}$ & Stem $(35,0 ; 36, A)$ \\
\hline Tabernaemontana rupicola Benth & IBS 4 & 000438 & Igapó Forest & Aerial parts $(37, \mathrm{O} ; 38, \mathrm{~A})$ \\
\hline
\end{tabular}

1. Floodplain forests flooded by blackwater rivers (Ferreira, 1997); 2. Tropical lowland densed forest (Oliveira, Nelson, 2000); 3. A low, relatively light forest with thin-stemmed trees $(10-20 \mathrm{~m})$ with large, broad-trunked individuals (Guilaumet, 1987).

albicans (ATCC 10231) were used and were grown in specific media (TSA, TSB, SDA and SDB, all from Difco). Preparation and standardization of microorganism suspensions were made according to techniques described elsewhere (Kubota, Ohara, 1998).

\section{Preparation of antibiotic solutions}

Dilutions at 40, 20, 10, 5, 3, 2, 1 and $0.5 \mu \mathrm{g} / \mathrm{mL}$ were prepared with cloramphenicol. Dilutions at 80,60 and $40 \mu \mathrm{g} / \mathrm{mL}$ were obtained for amphotericin B. In order to establish the minimal inhibitory concentration against the tested microorganisms, $10 \mathrm{ml}$ of all dilutions were transferred to the appropriate wells filled with $190 \mu \mathrm{L}$ of inoculated broth media (diluted 1:20).

\section{Dilution of the extracts}

The aqueous extracts $2,4,6,8,10,12,15,19,23,25$, $28,30,32,34,36$ and 38 (Table I) were prepared at the 
initial concentration of $50 \mathrm{mg} / \mathrm{mL}$; extract 17 (Table I) was diluted to $86.4 \mathrm{mg} / \mathrm{mL}$; and organic extracts $1,3,5,7,9$, $11,13,14,16,18,20,21,22,24,26,27,29,31,33,35$ and 37 (Table I) were prepared at the concentration of $50 \mathrm{mg} / \mathrm{mL}$. All dilutions were 20 times higher than the desired final concentration, so as to be diluted to the proper concentration after the addition to the microtiter plates. A mixture of water and DMSO was used as a solvent to dilute the organic extracts (1: 1) (Kubota, Ohara, 1998).

\section{Determination of antimicrobial activity in 96-well microtiter plates}

Inoculated broth seeded with $1 \times 10^{2} \mathrm{CFU} / \mathrm{mL}$ was used to the test and MIC determination, according to Mazzanti et al. (2000). Each extract was analyzed in octuplicates, and the technique was extracted and adapted from NCCLS protocols (2000). The results were visually evaluated according to the legend of table 2 .

\section{Calculation of MIC}

MIC tests were carried out using the extracts, chloramphenicol and amphotericin B, according to a modification of the procedures of NCCLS (2000) and Mazzanti et al. (2000). For the evaluation of the active extract, three dilutions at 50,25 and $12.5 \mathrm{mg} / \mathrm{mL}$ were prepared. Thus the final concentrations were $2.5,1.25$ and $0.625 \mathrm{mg} / \mathrm{mL}$ ( $1 / 20$ of the original dilutions).

\section{Phytochemical analysis}

Phytochemical analysis were performed in order to verify the presence of tanins, flavonoids (flavanon and flavanonols), alkaloids, saponins, anthraquinones and triterpenes (Costa, 1994a 1994b). The extract was diluted to $1,67 \mathrm{mg} / \mathrm{mL}$ to be tested for saponins and tanins, to $2 \mathrm{mg} / \mathrm{mL}$ to be tested for flavonoids, triterpenes and anthraquinones, and to $3 \mathrm{mg} / \mathrm{mL}$ to be tested for alkaloids.

\section{RESULTS AND DISCUSSION}

One out of the 38 extracts evaluated was considered active against $S$. aureus (organic extract obtained from stem of $T$. angulata), and 10 extracts were slightly active against $S$. aureus (aqueous extract from stem+leaves of Aspidosperma pachypterum \# 8, aqueous extract from leaves of Himatanthus attenuatus \# 25, aqueous extract and from leaves of Microplumeria anomala \# 30), $P$. aeruginosa (organic extract from leaves of Himatanthus attenuatus \# 16) and C. albicans (organic extract from stem + leaves of Aspidosperma sp. \# 9, organic extract from stem of Macoubea sprucei \# 20, aqueous and organic extracts from stem of Malouetia tamaquarina \# 24 and 25, organic extract from stem of Microplumeria anomala \# 27 and organic extract from stem of T. angulata \# 35).

The MIC obtained for the active extract lays ranges from 2.5 to $1.25 \mathrm{mg} / \mathrm{mL}$, and that obtained for standard cloramphenicol was $2 \mu \mathrm{g} / \mathrm{mL}$. Thus the activity of the selected extract cannot be considered high (Table II). We believe that the active substance is highly diluted in the crude extract. If bioguided fractionation is carried out, it will be possible to verify whether the outcome is loss or gain of antibacterial activity.

We have observed that some extracts were slightly active against the microorganisms tested, which could be related to growth inhibition; extracts with such activity were not, however, considered for further MIC determination (Table II).

Alkaloids were detected together with triterpenes, and the presence of alkaloids may be the responsible for the antibacterial activity observed in the crude organic extract from T. angulata. According to van Beek et al. (1984a), who studied a large number of Tabernaemontana sp. ethanolic extracts against bacteria, fungi, amoeba and virus, two out of 19 Tbernaemontana extracts showed activity against $S$. aureus (T. undulata and T. verticosa). In a continuous screening work, van Beek et al. (1985) have isolated forty five indol alkaloids from $T$. chipii, some of them presented significant activity against Gram-positive bacteria.

van Beek et al. (1984b) related a chemotaxonomy review on Tabernaemontana sp. showing the classification of indol alkaloids occurring in the genus, according to their biogenesis: vincosan, corynanthean, vallesiachotaman, strychnan, aspidospermatan, plumeran, eburnan, ibogan, tacaman, bis-indole and miscellaneous. In their work, the authors listed forty six out of seventy five Tabernaemontana species and their traditional use related to antimicrobial activity. Crude extracts as well as some indol alkaloids isolated from these species had been pharmacologically studied against bacteria. Verpoorte et al. (1983) studied antimicrobially active indol alkaloids belonging to Apocynaceae. Those manuscripts reinforce our aim of isolating indol alkaloids from $T$. angulata in order to correlate them with the primary antibacterial activity.

Apocynacee is also known to contain cardioactive glycosides, as in Nerium (Evans, 1996, Langford, Boor, 1996), Adenium (Yamaguchi, Abe, 1990) and Trachomitum (Waclaw-Rozkrutowa, 1975), and flavonoid glycosides and allies, as found in Parameria laevigata 
TABLE II - Results of the antimicrobial evaluation of the aqueous and organic extrats obtained from Brazilian Amazon Apocynaceae species and minimal inhibitory concentration of amphotericin B, cloramphenicol and the active extract 35 (organic extract obtained from stem of Tabernaemontana angulata). See Table 1 for meaning of extract numbers

\begin{tabular}{|c|c|c|c|c|}
\hline \multirow[b]{2}{*}{ Exract number } & \multicolumn{3}{|c|}{ Microorganism } & \multirow[b]{2}{*}{ MIC/microorganism } \\
\hline & $\begin{array}{l}\text { Candida } \\
\text { albicans }\end{array}$ & $\begin{array}{l}\text { Staphyllococus } \\
\text { aureus }\end{array}$ & $\begin{array}{l}\text { Pseudomonas } \\
\text { aeruginosa }\end{array}$ & \\
\hline 1 & ++ & ++ & +++ & \\
\hline 2 & +++ & ++ & +++ & \\
\hline 3 & ++ & ++ & +++ & \\
\hline 4 & +++ & ++ & +++ & \\
\hline 5 & +++ & ++ & +++ & \\
\hline 6 & +++ & +++ & +++ & \\
\hline 7 & +++ & ++ & +++ & \\
\hline 8 & +++ & + & +++ & \\
\hline 9 & + & +++ & +++ & \\
\hline 10 & +++ & ++ & +++ & \\
\hline 11 & ++ & ++ & +++ & \\
\hline 12 & $*$ & $*$ & $*$ & \\
\hline 13 & +++ & ++ & +++ & \\
\hline 14 & ++ & ++ & +++ & \\
\hline 15 & +++ & +++ & +++ & \\
\hline 16 & ++ & ++ & + & \\
\hline 17 & +++ & +++ & +++ & \\
\hline 18 & ++ & ++ & +++ & \\
\hline 19 & +++ & ++ & +++ & \\
\hline 20 & + & ++ & +++ & \\
\hline 21 & ++ & ++ & +++ & \\
\hline 22 & ++ & ++ & +++ & \\
\hline 23 & +++ & +++ & +++ & \\
\hline 24 & + & ++ & +++ & \\
\hline 25 & + & + & ++ & \\
\hline 26 & ++ & ++ & +++ & \\
\hline 27 & + & ++ & +++ & \\
\hline 28 & +++ & ++ & +++ & \\
\hline 29 & +++ & ++ & +++ & \\
\hline 30 & +++ & + & +++ & \\
\hline 31 & ++ & ++ & +++ & \\
\hline 32 & +++ & +++ & +++ & \\
\hline 33 & ++ & ++ & ++ & \\
\hline 34 & +++ & ++ & +++ & \\
\hline 35 & + & - & +++ & $2,5-1,25 \mathrm{mg} / \mathrm{mL} / S$. aureus \\
\hline 36 & +++ & ++ & +++ & \\
\hline 37 & ++ & ++ & +++ & \\
\hline 38 & +++ & ++ & +++ & \\
\hline Cloramphenicol & - & - & - & $\begin{array}{c}2,0 \mu \mathrm{g} / \mathrm{mL} / S \text {. aureus } \\
>2,0 \mu \mathrm{g} / \mathrm{mL} / P \text {. aeruginosa }\end{array}$ \\
\hline Amphotericin B & - & - & - & $<2,0 \mu \mathrm{g} / \mathrm{mL} /$ C. albicans \\
\hline
\end{tabular}

(-) no growth; $(+)$ colony growth and no broth turbidity; $(++)$ growth with slight broth turbidity; $(+++)$ growth and massive broth turbidity; $(*)$ extract not tested; MIC = minimal inhibitory concentration 
(Kamiya et al., 2001), Apocynum venetum (Sakushima et al., 1978), Cerbera mangas (Sakushima et al., 1976), Vinca minor (Szostak, Kowalewski, 1975), and Thevetia peruviana (Sticher, 1971). These two groups of compounds also may be found to cause the observed antimicrobial activity related to the stem organic extract of T. angulata Tannins, saponins, anthraquinones and flavonoids which are not detected by Shinoda's reagent were not found in the crude extract.

\section{ACKNOWLEDGEMENTS}

The authors want to thank Fundação de Amparo e Pesquisa do Estado de São Paulo - FAPESP - for the financial support (grant \# 99/05904-6).

\section{RESUMO}

\section{Atividade antibacteriana de extratos deApocynaceae e CIM de extrato orgânico de caule de Tabernaemontana angulata}

Trinta e oito extratos orgânicos e aquosos obtidos de 11 espécies de Apocynaceae foram submetidos a triagem utilizando o método da microdiluição em caldo contra Staphylococcus aureus, Pseudomonas aeruginosa $e$ Candida albicans. $O$ extrato orgânico obtido do caule de Tabernaemontana angulata apresentou atividade contra a bactéria Gram positiva S. aureus. A concentração inibitória mínima verificada para esse extrato variou de 2,50 a $1,25 \mathrm{mg} / \mathrm{mL}$. Cloranfenicol foi utilizado como antimicrobiano padrão. A análise fitoquímica indicou a presença de triterpenos e alcalóides no extrato ativo.

UNITERMOS: Apocynaceae. Tabernaemontana angulata. Atividade antibacteriana. Floresta Amazônica. CIM.

\section{REFERENCES}

COSTA, A. L. Farmacognosia. 5 ed. Lisboa: Calouste Gulbenkian, 1994a. v.1, 1031p.

COSTA, A. L.. Farmacognosia. 4 ed. Lisboa: Calouste Gulbenkian, 1994b. v.2, 1117p.

CRONQUIST, A. The Evolution and Classification of Flowering Plants. 2.ed. New York: The New York Botanical Garden Press, 1988. 555p.
DUKE, J. A., VASQUEZ, R. Amazonian Ethnobotanical Dictionary. Boca Raton: CRC Press. 1994. 215p.

EVANS, W.C. Pharmacognosy. 14. ed. London: WB Saunders. 1996. p. 318.

FERREIRA, L. V. Effects of the duration of flooding on species richness and floristic composition on three hectares in the Jaú National Park in floodplain forests in central Amazonia. Biodiversity Conservation, Boston, v.6, p.1353-63, 1997.

GUILLAUMET, J. L. Some structural and floristic aspects of the forest. Experientia, Basel, v. 43, p. 241-51, 1987.

KAMIYA, K, WATANABE, C, ENDANG, H, UMAR, M, SATAKE,T. Studies on the constituents of bark of Parameria laevigata Moldenke. Chem. Pharm. Bull., Tokio, v.49, n.5, p.551-7, 2001.

KUBOTA, K. Y., OHARA, M. T. Determinação do valor de concentração mínima inibitória de drogas e extratos vegetais pelo método da diluição em meio líquido utilizando microplacas. In: Simpósio de Iniciação Científica da Universidade de São Paulo, 6, Ribeirão Preto. Ribeirão Preto: USP, 1998. p.119.

LANGFORD, S.D., BOOR, P.J. Oleander toxicity: an examination of human and animal toxic exposures. Toxicology, Amsterdam, v.109, n.1, p.1-13, 1996.

MAZZANTI, G., MASCELLINO, N.T., PATTINELLI, L., COLUCCIA, D., MANGANARIO, M., SASO, L. Antimicrobial investigation of semipurified fractions of Ginkgo biloba leaves. J. Ethnopharmacol., Lausanne, v.71, n.12, p.83-88, 2000.

MOELLERING JUNIOR, R. C. Antibiotic Resistance: lessons for the Future. Clin. Infect. Dis., Chicago, v. 27, Suppl., S135-40, 1998.

OLIVEIRA, A.A., DALY, D.W. Geographic distribution of tree species occurring in the region of Manaus, Brazil: implications for regional diversity and conservation. Biodiversity Conservation, Boston, v.8, p.1245-59, 1999.

OLIVEIRA, A.A., NELSON, B.W. Floristic relationships of terra firme forests in the Brazilian Amazon. Forest Ecology and Management, Amsterdam, v. 146, p. 171181, 2001. 
SAKUSHIMA A, NISHIBE, S., HISADA, S. Studies on the constituents of Apocynaceae plants. Isolation of flavonol glycosides and other components from the leaves of Apocynum venetum L. var. basikurumon Hara. Yakugaku Zasshi, Tokio v.98, n.10, p.1395-7, 1978.

SAKUSHIMA, A., NISHIBE, S., HISADA, S., NORO,Y., HISADA,Y. Studies on the constituents of Apocynaceae plants; isolation of flavonol glycosides and some other components from the leaves of Cerbera manghas L. Yakugaku Zasshi, Tokio, v.96, n.8, p.1046-8, 1976.

STICHER, O. Thevesid a new iridoid-glycoside from Thevetia peruviana (Pers.) K. SCHUM. (Thevetia neriifolia Juss.) (Apocynaceae). Pharm. Acta Helv., Zurich, v.46, n.3, p.156-66, 1971.

SZOSTAK, H., KOWALEWSKI, Z. The flavonoids in the leaves of Vinca minor L. (Apocynaceae). Pol. J. Pharmacol. Pharm., v.27, n.6, p.657-63, 1975.

VAN BEEK, T.A., VERPOORTE, R., SVENDSEN, A.B. Antimicrobially active alkaloids from Tabernaemontana chipii.J. Nat. Prod., Pittsburgh, v.48, n.3, p.400-23, 1985.

VAN BEEK, T.A., DEELDER, A.M., VERPOORTE, R., SVENDSEN, A.B. Antimicrobial, antiamoebic, and antiviral screening of some Tabernaemontana species. Planta Med., Stuttgart v.50, n.2, p.180-5, 1984a.
VAN BEEK, T.A., VERPOORTE, R., SVENDSEN, A.B., LEEWENBERG, A.J.M., BISSET, N.G. Tabernaemontana L. (Apocynaceae): a review of its taxonomy, phytochemistry, ethnobotany and pharmacology. J. Ethnopharmacol., Lausanne, v.10, n.1, p.1-156, $1984 b$.

VERPOORTE, R., VAN BEEK, T. A., THOMASSEN, P.H.A.M., AANDEWIEL, J. T.A., SVENDSEN, A.B. Screening of antimicrobial activity of some plants belonging to the Apocynaceae and Loganiaceae. $J$. Ethnopharmacol., Lausanne, v.8, p.287-302, 1983.

WACLAW-ROZKRUTOWA, B. Cardenolides of Trachomitum sarmatiense Woodson. Pol. J. Pharmacol. Pharm., v.27, n.4, p.455-60, 1975.

YAMAUCHI, T., ABE, F. Cardiac glycosides and pregnanes from Adenium obesum (studies on the constituents of Adenium. I). Chem. Pharm. Bull., Tokyo, v.38, n.3, p.669-72, 1990.

YOUNES, R.N., VARELLA, A.D., SUFFREDINI, I.B. Extração e rastreamento de novas drogas em plantas brasileiras. Acta Oncol. Bras., São Paulo, v.20, p.15-19, 2000.

Recebido para publicação em 29 de março de 2001. 